\title{
Imitates and Surpasses: Intertextual Reading of $A$ Child Who Sells His Smile
}

\author{
Min Li \\ School of Teacher Education, Qujing Normal University, Qujing Yunnan 655011, China
}

Keywords: A Child Who Sells His Smile, Intertextuality, Framed structure, Imitate and surpass

\begin{abstract}
A Child Who Sells His Smile is the German children's literature writer James Krüss' masterpiece. The novel has distinct intertexuality characteristics. James Krüss extensively absorbed Germany, Italy and other European classical works of writers nutrition.His novel not only imitated but also beyond the framed structure of Arabian Nigths and Decameron. On the basis of imitate and learn A Man Who Sells His Shadow and Cold Heart, He had formed his own creative features.
\end{abstract}

\section{Introduction}

"Timm Thaler oder Das verkaufte Lachen", published in 1962, is the materpiece of James Krüss (1926-1997), a famous childrens literature writer in Germany. James Krüss was no doubt a very important writer of German childrens literature in 20 centuries. Krüss stepped into literature circles in his youth. Under the encouragement of another childrens literature writer Erich Kastner, he started devoting to the childrens literature creation and large amount of his works had been published. Except for "Timm Thaler oder Das verkaufte Lachen", his representive works include "My Great Grandfather and I", "Tim Tall's Toy Doll", etc. He has won Germany Childrens Literature Awards for many times and won the Hans Christian Andersen Award in 1968.

Intertextuality can be also called textual interaction, which refers to the interaction relationship between two texts or more. French literary critic Julia Kristeva has pointed out in her work "Semiotics, Analytical Research on Semanteme" that "Any text is like a built-up piece made up by sayings and images, by absorbing and converting from other texts." Any text is not an isolated existence, more or less influenced by predecessors' works with intertextuality." "1] Roland Barthes believes that, "any text is a kind of intertextuality and in one text there exist other texts in varying degrees and various recognizable forms. Take the texts in previous culture and around for example. Any text is reorganization of the past citations. You enter into texts, you will get the re-distributional code sections, phrases, rhythmic patterns and social verbal collections.” ${ }^{[2]}$

By the analysis on James Krüss's "Timm Thaler oder Das verkaufte Lachen" according to this theory, we can clearly find the intertextuality between it and other frame type structured works such as "The Thousand and One Nights", "Decameron”, Adelbert von Chamisso's "The Man Who Sells His Own Shadow”, and Wilhelm• Hauff's “The Cold Heart”.

\section{The imitation and transcendence of frame type structure}

"Timm Thaler oder Das verkaufte Lachen" has used the frame type structure of "The Thousand and One Nights" and "Decameron" for reference by telling stories in stories. In "The Thousand and One Nights", the ruler Shahryār was born violently. He married a girl every night and then got her killed in the next morning. Schehemzade, the minister's daughter who wanted to save all girls in the country, decided to marry the king. She told stories to the king every night and stopped before the dawn when the story was in the climax, which interested and pleased the king very much. After 1001 nights' story telling, the king finally came to his regret realizing his faults and determined to corret all errors.

In the Italian writer Baccaccio's " Decameron", a serious plauge broke out in the year of 1368 in Europe. Corpses strewed the field of the prosperious Florence, where was a big mess. Ten young men and women had the chance to survive in the catastrophe, who came to a cottage on a mountain outside 
the city. They decided to tell a story by turns everyday to kill time and relieve the loneliness. They have lived together for about ten days telling each other almost 100 stories totally.

In "Timm Thaler oder Das verkaufte Lachen", "I" went to Leipzig supervising the publication of a picture album which instructed people to know currencies, and then met the old acquaintance Timm. Timm took seven days to represent me a story of a child selling his laugh in the proofreading room. As an excellent writer, he could definitely surpass precursors on the basis of referring to them and develop his own style. There is no doubt that "Timm Thaler oder Das verkaufte Lachen" is the production which has exceeded many previous texts in many aspects.

"Timm Thaler oder Das verkaufte Lachen" and "Decameron" uses the structure of stories covered by stories. There are many short stories in the long stories. "Timm Thaler oder Das verkaufte Lachen" tells a story of the little boy Timm's growing experience from 3 to 16 years old by vivid and fine narration. To explain further, no matter in “The Thousand and One Nights” and "Decameron”, the narrator is simply the story teller who narrates several stories independent with each other. There is no interweaving in reality between the narrator and characters narrated in stories. But in "Timm Thaler oder Das verkaufte Lachen", Timm is both the name of story narrator and the character in the story who sells laugh. Timm told “me”, “I don't know whether this is my story or not although I act always, this might be the one.” [3] In this way, the story narrator tells has become the story about himself, and this kind of narrating perspective can make the reader naturally fall into the scene in the story, agree the content of the story and regard the fictional story as the real event. James Krüss has made his efforts on this by special elaborations. For example, in the work, "I", a writer, before meeting the good friend Timm, was treated for an unforgettable meal by a stranger in the compartment from "Ms maag debao to Leipzig”. After listening to Timm's story, "I" met the strange sir who had bought me meal in the same compartment of the train. He did not hope that "I" would write down Timm's story and wanted to offer to buy my silence but turned down by me. This strange sir was exactly the human devil Lefet. The character Lefet in the story intruded into and interweaved with "my" real life. This innovative narrative technique has greatly improved the real credibility of story and shortened the distance between the fictional world and the real world greatly.

\section{The imitation and transcendence of"The Man Who Sells His Own Shadow" and "The Cold Heart”}

The name "Timm Thaler oder Das verkaufte Lachen" makes people think of German writer Chamisso's “The Man Who Sells His Own Shadow”, and Wilhelm Hauff's "The Cold Heart”. "The Man Who Sells His Own Shadow" tells a story from the first person's perspective that, "I”, Peter ShiLeiMi sold his shadow to a man in grey and gained a large fortune. But without shadow, he was feared of people's mocking. Due to this he even lost his true love. Faced with these deadly blows, he finally restricted his desire and gave up the deal which could help him to get his shadow back but agreed to sell his soul to the man in grey. Peter ShiLeiMi with no shadow of himself, but on his magic boots, he walked around the whole world devoting himself into the exploration of nature and science. "The Cold Heart" tells a story that Peter Munch, a charcoal burner living in the dark forest wishes to obtain big fortune without any working. He looked for the little Mr. glass who promised him to satisfy three dreams. Thus he got huge fortunes but finally vanished due to his greediness and foolishness. At the end of his rope, he sold out his heart to the devil getting back a stone heart. At last, with the help of the little Mr. glass, he won his heart back and lived happily with his mom and wife.

Like Chamisso's “The Man Who Sells His Own Shadow”, and Wilhelm Hauff's “The Cold Heart”, there is also an unbelievable deal in "Timm Thaler oder Das verkaufte Lachen". Peter ShiLeiMi in "The Man Who Sells His Own Shadow" sold out his shadow to the man in grey so as to acquire endless fortunes, and Peter Munch in "The Cold Heart" made a deal with the devil by selling his own heart to get huge fortunes and a stone heart. Timm in "Timm Thaler oder Das verkaufte Lachen" sold his laugh to the human devil Lefet getting back the ability of being the winner in gambling forever. Three works above have represented the humanity's alienation by money which resulted in the aloof relationship between people. These works also reveal the evil of money and make denouncement on money. 
Compared with "The Man Who Sells His Own Shadow”, and "The Cold Heart”, there are at least some transcendences in "Timm Thaler oder Das verkaufte Lachen" presented as below. Firstly, the character Timm, as a kid, he has a pure purpose of getting money to make his stepmother live better and for himself get an independent room. As a kid remaining pure nature, he does not have too much desire for money, let alone thinking about lavishing money, instead, he would like to help other people out of difficulties by using money. In “The Man Who Sells His Own Shadow”, and “The Cold Heart", both of two characters are adults who start squandering after getting money. Peter in "The Cold Heart" spends money like water but mean to his own family. He even gets his wife killed because of money finally as poor as a church mouse. Peter ShiLeiMi in "The Man Who Sells His Own Shadow" starts wasting and dissipating money after getting rich and finally money gets him into dilemmas once again. But Timm in "Timm Thaler oder Das verkaufte Lachen" has many good friends with justice and sympathy, so with their help, Timm fight with Lefet by his wits and courage and finally won back his own laugh. In the former two works, there are no friends around the characters to help them get out of difficulties. In the end of story, they succeeded getting the heart back with the help of little Mr. glass, or by his own fighting lose the shadow forever. In "Timm Thaler oder Das verkaufte Lachen", there was a clause in the contract between Timm and Lefet regulating that if Timm failed one time in gambling, Lefet had the obligation to give Timm's laugh back. But in "The Man Who Sells His Own Shadow", and "The Cold Heart" once-for-all” deals, once the contract has been signed, there would be no possibility to cancel. It was because of the clause in "Timm Thaler oder Das verkaufte Lachen", Timm could use it to find back his laugh.

\section{Conclusion}

Roland Barthes thinks that, "every text is actually turning back to reference the "sea" gathered by countless texts, and a text is no single but a plural weaving activity." [4] The well-known novelist Milan Kundera believes that "the spirit of novel is continuous and every work is the response to its past and every work contains the past experience of the novel.” [5]

We can see from Krüss's strong awareness of intertextuality through deep study on the text of "Timm Thaler oder Das verkaufte Lachen". Except the intertextuality relation with above works, "Timm Thaler oder Das verkaufte Lachen" has the inter-reference relation with Erich Keith Turner's "Emil und die Detektive”, novels of Charles Dickens', and later Michael Ende’s "Maomao: time thieves and a little girl's incredible story". At the beginning of "Timm Thaler oder Das verkaufte Lachen", "I” met the stranger and the following story was closely related to him, which made us think about the work "Emil und die Detektive". In this story, Emil met a thief on the train and later he had a soul-stirring experience. There are happy endings in novels of Charles Dickens. His works have been mentioned in "Timm Thaler oder Das verkaufte Lachen". Obviously, James Krüss is quite familiar with Charles Dickens and deeply influenced by him so that he gives a happy ending in "Timm Thaler oder Das verkaufte Lachen". In this work, the boy Timm sold out his laugh to the human devil Lefet, and the city residents in "Maomao: time thieves and a little girl's incredible story" sold their time to Mr. Grey. Lefet and Mr. Grey both get extra profits by harming others to benefit themselves in these deals.

To sum up, "Timm Thaler oder Das verkaufte Lachen" has modified and surpassed the predecessors' texts on the basis of imitating them. The process of imitation, modification and transcendences has apparently formed the intertextuality with the predecessors' texts. IT is exactly on the basis of adopting predecessors' essences, James Krüss can innovate and surpass himself continuously so that the later comers can surpass the formers and his works can become the masterpieces known by the whole world.

\section{References}

[1] Tiphaine Samoyault. Research on intertextuality. Translated by Shao Wei, Tianjin: Tianjin Peoples Publishing House,2002:15 
[2] Roland Barthes. Text Theory. Translated by Zhang Yinde. Shanghai Literary Theory,1987, (5):97

[3] James Krüss. Timm Thaler oder Das verkaufte Lachen. Translated by Li Yongcan. Jinan: TOMORROW PUBLISHING HOUSE ,2011:6

[4] Feng Shounong. Roland Barthes: From Structuralism to the Anti-structuralism. Wenyi Zhengming Magzine,1991, (2).

[5] Milan Kundera. The Art of Fiction. Translated by Dong Qiang. Shanghai: Shanghai Translation Publishing House,2004:24 